\title{
A COMPARATIVE STUDY ON THE MECHANISM OF ACTION OF MORPHINE ON GASTRIC ACID SECRETION IN DOGS
}

\author{
Isamu YAMAGUCHI \\ Research Lahoratories, Fujisana Pharmaceutical Co. Ltd, \\ Yodogawa-ku, Osaka, Japan
}

Accepted July 23, 1974

\begin{abstract}
While researching the mechanisms of gastric secretagogue action of morphine, the effects of hexamethonium, atropine and secretin on morphine-induced gastric secretion were studied, and were compared with those on food-, histamineand tetrapeptide-induced gastric secretion in conscious dogs, and on histaminc-, tetrapeptide- and bethanecol-induced gastric secretion in anesthetized dogs. Effect of acute bilateral vagotomy on the gastric secretion was also investigated in anesthetized dogs. Results are discussed in relation to the mechanisms involved in the stimulation and inhibition of gastric secretion, and the following suggestions are made. Direct vagal excitation of oxyntic glands and endogenous gastrin plays an important role in food-induced secretion in imnervated and dencrvated fundic pouches, respectively. Exogenous gastrin stimulates gastric secretion activating cholinergic post-ganglionic nerve fibers in conscious dogs. In anesthetized dogs, however, exogenous gastrin induces its secretagogue action mainly by a direct action on oxyntic glands. A close similarity was observed between morphine-induced secretion and food-induced secretion in denervated fundic pouches when inhibitory activitics of drugs were compared. It is thus concluded that endogenous gastrin plays an important role in the gastric secretion induced by morphine.
\end{abstract}

The action of morphine which increases gastric secertion was first reported by Riegel (1) as early as in 1900 and it was later shown by Smirnov and Schirokij (2) that this increase is achieved by way of the vagus nerve. The fact that this nerve plays a critical role in the mechanism of physiological gastric secretion is now widely accepted. Uvnäs (3) has commented that vagal activation causes not only gastrin release from the antrum, but also directly stimulates the oxyntic glands to secrete hydrochloric acid. Thus morphine releases gastrin or stimulates parietal cells by a direct vagal action.

Grechishkin (4) proposed that endogenous histamine plays an important role in the gastric secretion in so far as histamine levels were elevated following the administration of morphine (5).

The present paper is concerned with a study in which the effect of hexamethonium, i.e. a ganglion blocker, atropine, and secretin on morphine-induced gastric secretion was compared with that on food-, tetrapeptide-, histamine- and bethanecol-induced gastric sccretion in anesthetized or unanesthetized dogs.

\section{MATERIALS AND METHODS}

Anesthetized dogs

Mongrel dogs of both sexes weighing about $10 \mathrm{~kg}$ were fasted for $24 \mathrm{hr}$ and anes- 
thetized with either $10 \mathrm{mg} / \mathrm{kg}$ of morphine hydrochloride s.c. and $1.5 \mathrm{~g} / \mathrm{kg}$ of urcthane s.c., or $75 \mathrm{mg} / \mathrm{kg}$ of chloralose and $1.5 \mathrm{~g} / \mathrm{kg}$ of urethane s.c. The pylorus and esophagus were ligated, the ventral wall of the stomach was cannulated, and the animals were placed in a prone position. Gastrin tetrapeptide, histamine dihydrochloride, and bethanecol chloride were cach continuously infused into a femoral vein at a rate of $0.03,0.3$, and 0.6 $\mathrm{mg}$ per hour, respectively. Throughout the entire period of experiments, physiological saline $(0.9 \% \mathrm{NaCl})$ was infused i.y. at a rate of $30 \mathrm{ml}$ per hour to maintain water load. Unanesthetized dogs

Male and female beagle dogs weighing 6 to $12 \mathrm{~kg}$ were used. A vagally innervated fundic pouch (Pavlov's pouch), and a denervated fundic pouch (Heidenhain's pouch) were prepared by conventional methods under pentobarbital anesthesia. Two or three weeks later, these animals were injected i.v. with 2-deoxy-D-glucose in order to investigate the presence or absence of functional vagal supply to the pouches. After a fast of 24 hours, they were fed $150 \mathrm{~g}$ of canned hecf to stimulate gastric secretion.

Dosing and determination of gastric secretion

The volume of gastric juice was measured in a graduated cylinder every $15 \mathrm{~min}$, and the acidity by titration with $0.1 \mathrm{~N} \mathrm{NaOH}$ up to $\mathrm{pH} 7$ with an automatic litrator (Hiranuma, Japan). Hexamethonium bromide, atropine sulfate, and secretin (Boots) were dissolved in physiological saline, injected i.v., and the volume of the gastric juice was compared with that hefore administration.

TABL: 1. Effect of drugs on gastric secretory volume in anestherized dogs

\begin{tabular}{|c|c|c|c|c|c|c|c|c|c|}
\hline \multirow{3}{*}{ Drugs } & \multirow{3}{*}{$\begin{array}{c}\text { Dose } \\
\mathrm{mg} / \mathrm{kg}\end{array}$} & \multirow{2}{*}{\multicolumn{2}{|c|}{ Morphine }} & \multirow{2}{*}{\multicolumn{4}{|c|}{\begin{tabular}{l}
\multicolumn{2}{c}{ stimulated by } \\
Tetrapeptide Histamine
\end{tabular}}} & \multirow{2}{*}{\multicolumn{2}{|c|}{ Bethanecol }} \\
\hline & & & & & & & & & \\
\hline & & $\begin{array}{l}\text { inhibi- } \\
\text { tion } \%\end{array}$ & $\begin{array}{c}\mathrm{ED50} \\
\mathrm{mg} / \mathrm{kg}\end{array}$ & $\underset{\%}{\text { inhibition }}$ & $\begin{array}{c}\mathrm{ED} 50 \\
\mathrm{mg} / \mathrm{kg}\end{array}$ & $\underset{\%}{\text { inhibition }}$ & $\begin{array}{l}\text { ED50 } \\
\mathrm{mg} / \mathrm{kg}\end{array}$ & $\underset{\%}{\operatorname{inhibition}}$ & $\begin{array}{r}\mathrm{EDS0} \\
\mathrm{mg} / \mathrm{kg}\end{array}$ \\
\hline \multirow[t]{3}{*}{ Hexamethonium } & 0.064 & 24.3 & & & & & & & \\
\hline & 0.25 & 59.1 & 0.30 & & & & & & \\
\hline & 1.0 & 61.3 & & 21.1 & & 20.2 & & 12.6 & \\
\hline \multirow[t]{7}{*}{ Atropine } & 0.00025 & & & & & & & 37.4 & \\
\hline & 0.001 & 0 & & & & & & 50.0 & 0.0006 \\
\hline & 0.004 & 46.4 & & & & & & 92.0 & \\
\hline & 0.016 & 55.6 & 0.0066 & & & & & & \\
\hline & 0.064 & 73.9 & & 31.8 & & 5.4 & & & \\
\hline & 0.25 & & & 42.6 & & 39.8 & & & \\
\hline & 1.0 & & & 44.1 & & 33.7 & & & \\
\hline \multirow[t]{5}{*}{ Secretin } & $2.0^{*}$ & 27.6 & & 9.2 & & & & & \\
\hline & $4.0^{*}$ & 85.1 & $3.0^{*}$ & & & & & & \\
\hline & $8.0^{*}$ & 91.2 & & 45.7 & $16^{*}$ & 0 & & 28.0 & \\
\hline & $16.0^{*}$ & & & & & 14.6 & $23^{*}$ & & $14^{*}$ \\
\hline & $32.0^{*}$ & & & 57.6 & & 85.4 & & 84.8 & \\
\hline
\end{tabular}

Inhibition percent represents the maximal inhibition percent within one hour after administration of the drug, and each value is the mean of 3 animals. ED50 values were outlined on the graph on semilogarithmic paper. *units per $\mathrm{kg}$. 


\section{RESULTS}

Anesthetized dogs

The effect of hexamethonium, atropine and secretin on the secretory volume stimulated by morphine, tetrapeptide, histamine and bethanecol is shown in Table 1.

(a) Effect of drugs on morphine-induced gastric secretion

A considerable amount of gastric juice was secreted in dogs anesthetized with morphine-urethane. The volume and acid concentration were $5-20 \mathrm{ml} / 15 \mathrm{~min}$ and $100-150$ $\mathrm{mEq} / \mathrm{l}$, respectively.

Intravenously given atropine sulfate $(0.004-0.064 \mathrm{mg} / \mathrm{kg})$ and hexamethonium bromide $(0.064-1.0 \mathrm{mg} / \mathrm{kg})$ reduced the volume, and the effect of the drugs was found to be doserelated. Nevertheless these drugs reduced the acid concentration very little.

Secretin (2-8 units $/ \mathrm{kg}$ ) markedly reduced not only the volume but also the acid concentration. The onset of the antisecretory action of secretin was immediate and of short duration.

(b) Effect of drugs on tetrapeptide-, histamine-and hethanecol-induced gastric secretion

In dogs anesthetized with chloralose-urethane, spontaneous gastric secretion was not observed. The gastric juice was secreted immediately after the start of the continuous infusion of tetrapeptide, histamine, or bethanecol. The volume and acid concentration rose gradually and reached a plateau about $90 \mathrm{~min}$ later, with the values of $5-20 \mathrm{ml} / 15$ min and $100-150 \mathrm{mEq} / \mathrm{l}$, respectively.

Hexamethonium did not inhibit tetrapeptide-, histanine-, and bethancol-induced gastric secretion even at a dose as high as $1 \mathrm{mg} / \mathrm{kg}$. This dose had inhibited the morphineinduced gastric secretion.

Atropine inhibited bethanecol-induced secretion slightly at a small dose of 0.00025 $\mathrm{mg} / \mathrm{kg}$, and almost completely at $0.004 \mathrm{mg} / \mathrm{kg}$. Atropine was found to be about ten times more effective on bethanecol-induced secretion than on morphinc-induced secretion, but the tetrapeptide- and histamine-induced secretion was slightly inhibited only in high doses.

Secretin inhibited tetrapeptide-, histamine-, and bethanecol-induced secretion to approximately the same extent. The activity was about one-fifth of that on morphineinduced secretion. Secretin reduced both the volume and acid concentration.

(c) Effect of cervical vagotomy on morphinc-, tetrapeptide-, histamine- and bethanecotinduced gastric secretion

The volume of gastric juice in dogs anesthetized with morphine-urethane was reduced to $20 \%$ of the control $30 \mathrm{~min}$ after bilateral vagotomy at the neck, and then recovered to approx. $50 \%$ of the control (Fig. 1).

Tetrapeptide-induced secretion was also inhibited by vagotomy. The volume decreased to about $30 \%$ of the control with the concomitant decrease in acid concentration, but returned to about $85 \%$ that of the control 75 min thereafter (Fig. 2).

Histamine- and bethanecol-induced secretion were not affected by vagotony. 


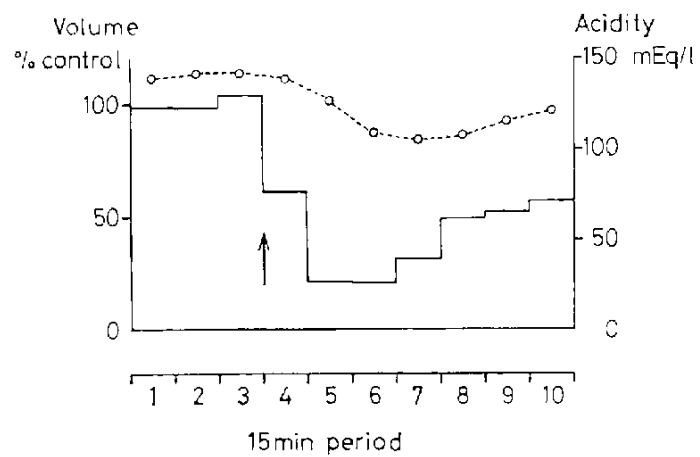

Fili. 1. Effect of vagotomy on the morphine-induced gastric secretion. Volume of gastric juice is expressed as percent of the mean of three periods $100 \%=10.8$ $\mathrm{ml} / 15 \mathrm{~min}$ ). Volume (solid line) and acidity (broken line) represent the mean of five experiments in each of 5 animals. Bilateral vagotomy at the neck was performed at the arrow.

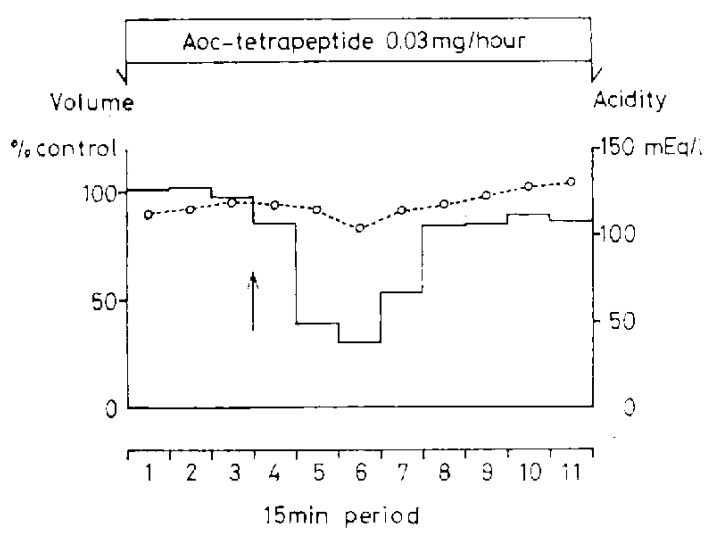

FICi. 2. Effect of vagotomy on the tetrapeptide-induced gastric secretion. Volume of gastric juice is expressed as percent of the mean of three periods $(100 \%-$ $13.4 \mathrm{ml} / 15 \mathrm{~min}$ ). Volume (solid line) and acidity (broken line) represent the mean of three experiments in each of 3 animals. Bilateral vagotomy at the neck was performed at the arrow.

\section{Unanesthetized dogs}

The effects of hexamethonium, atropine and secretin on the secretory volume stimulated by food, tetrapeptide and histamine are shown in Table 2.

\section{(a) Effect of drugs on food-induced gastric secretion}

The volume and acid concentration gradually increased after feeding, and reached maxima of 5-8 $\mathrm{ml} / 15 \mathrm{~min}$ and $160 \mathrm{mEq} / \mathrm{l}$, respectively, at about $1 \mathrm{hr}$, and then gradually decreased.

Atropine dose-dependently reduced the volume and acid concentration. This inhibitory action was rapid and prolonged and, in dogs with an innervated fundic pouch 
TABLL: 2. Effect of drugs on gastric secretory yolume in conscious dogs with innervated or denervated fundic pouch.

\begin{tabular}{|c|c|c|c|c|c|c|c|c|c|}
\hline \multirow{3}{*}{ Drugs } & \multirow{3}{*}{$\begin{array}{l}\text { Dose } \\
\mathrm{mg} \text { kg }\end{array}$} & \multirow{2}{*}{\multicolumn{2}{|c|}{$\begin{array}{l}\text { Innervated pouch } \\
\text { stimulated by } \\
\text { food }\end{array}$}} & \multicolumn{6}{|c|}{ Denervated pouch stimulated by } \\
\hline & & & & foo & & Tetrape & ptide & Hista & mine \\
\hline & & $\underset{\%}{\operatorname{inhibition}}$ & $\begin{array}{l}\text { ED50 } \\
\mathrm{mg} / \mathrm{kg}\end{array}$ & $\underset{\%}{\text { inhibition }}$ & $\begin{array}{r}\text { ED50 } \\
\mathrm{mg} / \mathrm{kg}\end{array}$ & $\underset{\%}{\text { inhibition }}$ & $\begin{array}{l}\text { ED50 } \\
\mathrm{mg} / \mathrm{kg}\end{array}$ & $\begin{array}{l}\text { inhibi- } \\
\text { tion } \%\end{array}$ & $\begin{array}{l}\mathrm{ED} 50 \\
\mathrm{mg} / \mathrm{kg}\end{array}$ \\
\hline \multirow[t]{4}{*}{ Hexamethonium } & 0.125 & 3.7 & & & & & & & \\
\hline & 0.25 & 42.4 & 0.48 & 39.2 & & & & & \\
\hline & 0.50 & 40.5 & & 59.2 & 0.40 & & & & \\
\hline & 1.0 & 75.1 & & 63.9 & & 4.0 & & 0 & \\
\hline \multirow[t]{5}{*}{ Atropine } & 0.00025 & 26.5 & & & & 33.9 & & & \\
\hline & 0.001 & 60.0 & 0.00067 & 29.1 & & 54.6 & 0.00061 & & \\
\hline & 0.004 & 73.8 & & 48.6 & 0.0034 & 92.3 & & & \\
\hline & 0.016 & & & 82.2 & & & & & \\
\hline & 1.0 & & & & & & & 27.0 & \\
\hline \multirow[t]{4}{*}{ Secretin } & $4.0^{*}$ & & & 31.2 & & 30.2 & & & \\
\hline & $8.0^{*}$ & 33.7 & & 60.5 & $6.6^{*}$ & 54.1 & $7.7^{*}$ & & \\
\hline & $16.0^{*}$ & 51.8 & $13.7^{*}$ & 73.1 & & 66.5 & & & \\
\hline & $32.0^{*}$ & 78.8 & & & & & & 34.1 & \\
\hline
\end{tabular}

See Table 1 .

was about five and ten times as potent as in dogs with a denervated fundic pouch and anesthetized with morphine-urethane, respectively. The effect of atropine in dogs with an innervated fundic pouch was in agreement with its effect on bethanecol-induced gastric secretion in anesthetized dogs.

Hexamethonium reduced the volume of gastric secretion in dogs with a fundic pouch. This inhibitory effect of hexamethonium was approx. equal to that of the morphine-induced secretion.

Secretin reduced food-induced secretion, and was found to be somewhat more potent in dogs with denervated fundic pouches than in those with innervated fundic pouches.

(b) Effect of drugs on tetrapeptide-and histamine-induced gastric secretion in dogs with denervated fundic pouch

Continuous infusion of tetrapeptide and histamine promptly elicited gastric secretion. The volume and acid concentration rose gradually and reached a plateau about $60 \mathrm{~min}$ after the start of the infusion. The peak secretory volume and acid concentration werc $3-12 \mathrm{ml} / 15 \mathrm{~min}$ and about $150 \mathrm{mEq} / \mathrm{l}$, respectively.

Tetrapeptide stimulation: Hexamethonium did not inhibit tetrapeptide-induced secretion in a dose as high as $1 \mathrm{mg} / \mathrm{kg}$. This was in agreement with the results in anesthetized dogs.

The inhibitory activity of atropine was the strongest, and was approx. equal to that on food-induced secretion in denervated fundic pouches, and on bethanecol-induced secretion in anesthetized dogs. 
Secretin (4-16 units $/ \mathrm{kg}$ ) reduced the volume to approx. the same extent as it did against the food-induced secretion in dogs with denervated fundic pouches. The reduction in acid concentration was slight and the percent inhibition ranged from 10 to $20 \%$.

Histamine stimulation: Hexamethonium $1 \mathrm{mg} / \mathrm{kg}$ had practically no effect.

Atropine reduced the volume by only $27 \%$ during the first 15 -min period when given in doses as high as $1 \mathrm{mg} / \mathrm{kg}$. This inhibition was recovered during the following $60 \mathrm{~min}$. There was no apparent change in acid concentration.

Immediately after the injection of secretin ( 32 units $/ \mathrm{kg}$ ), the volume decreased to $34.1 \%$ and recovered gradually in the subsequent 60 min. Acid concentration decreased by about $5 \%$.

\section{DISCUSSION}

Atropine inhibited food-induced gastric secretion in dogs with a denervated fundic pouch. This finding indicates that atropine inhibits not only acid secretion from the oxyntic glands, but also the release of gastrin from the antrum. However, atropine was about 5 times more effective on inhibiting food-induced secretion in dogs with innervated fundic pouches than in those with denervated fundic pouches. Thus there appears to be a difference in sensitivity to the inhibitory influence by atropine between gastrin release and acid secretion. This is presumably due to the difference in the distribution of the vagus nerve between the fundus and the antrum. Yamaguchi et al. (6) have demonstrated histochemically that there the cholinergic innervation in the fundus is more dense than in the antrum. On the other hand, the inhibitory activity of atropine in innervated pouches is approx. equal to that on bethanecol-induced secretion in anesthetized dogs. These results suggest that direct vagal excitation of oxyntic glands plays a major role in the foodresponse of innervated fundic pouches, while endogenous gastrin is important in the foodresponse of denervated fundic pouches.

Hexamethonium inhibited the food-induced secretion in both the denervated and innervated fundic pouches, whilc the drug inhibited little bethanecol-induced secretion in anesthetized dogs. The ganglionic transmission appears to be involved in the release of gastrin as well as in the direct vagal excitation of oxyntic glands. Elwin and Uvnäs (7) showed that release of gastrin from the antrum induced by food was blocked by hexamethonium.

Atropine strongly inhibited the tetrapeptide-induced secretion in dogs with denervated fundic pouches. This inhibitory activity of atropine was approx. the same as that against the food-induced secretion in innervated fundic pouches. It is postulated that exogenous gastrin stimulates gastric secretion through the activation of intramural cholinergic nerves. Hirschowitz and Sachs (8) also reported that gastrin or gastrin-like peptides act cholinergically either being mediated by acetylcholine or by combining with muscarinic receptors. In dogs with denervated fundic pouches, hexamethonium did not inhibit the tetrapeptide-induced secretion in a dose depressing the food-induced secretion. This shows that the exogenous gastrin action is mediated by acetylcholine from the post- 
ganglionic cholinergic nerves, and is independent of preganglionic cholinergic activity.

In contrast to the results in conscious dogs, a fairly large dose of atropine induced only a weak inhibitory effect on the tetrapetide-induced secretion in anesthetized dogs. It has also been reported that gastrin-induced secretion in anesthetized cats (9) and rats (10) is resistant to the inthibitory influence of atropine and differs in this respect from the gastrin-induced secretion in conscious cats (11) and rats (12). These results indicate that exogenous gastrin neither activates intramural cholinergic nerves nor stimulates directly muscarinic receptors in anesthetized animals. The cholinergic nerves or the muscarinic receptors appear to be blocked by anesthetics used. In our study, however, the integrity of muscarinic receptors was evidenced by the fact that bethanecol provoked atropinesensitive acid secretion in anesthetized dogs, which, in turn, supports the previous assumption that exogenous gastrin does not directly stimulate the muscarinic receptors. The view is favored that anesthetics inhibit acetylcholine release from the postganglionic cholincrgic nerves which may be initiated by gastrin. however, direct determination of aceiylcholine release should be carried out. Under the influence of anesthetics, exogenous gastrin appears to stimulate gastric secretion by a direct action on parietal cells.

Atropine, hexamethonium and secretin produced the same degree of inhibition on morphine-induced secretion as they did against the food-induced secretion in denervated fundic pouch of the conscious dogs in which endogenously released gastrin plays an important part. On the other hand, atropine was about ten times more effective on the bethanecol-induced secretion and the food-induced secretion than on the morphine-induced secretion, while secretin was more effective on the latter than on the former two. These results show the similarity between morphine- and endogenous gastrin-induced secretion, and difierentiate the former from the secretion stimulated by direct cholinergic activation of oxyntic glands. It can be concluded that the enhanced secretion following morphine results from endogenous gastrin rather than from the direct vagal activation of oxyntic glands. In fact, serum levels of gastrin have recently been found to be much higher in dogs treated with morphine than in fasted conscious and unconscious dogs (13).

Vagotony promptly inhibited the morphine-induced secretion, but the inhibition was recovered to about $50 \%$ of control. Initial transient inhibitory effect of vagotomy was also seen in the tetrapeptide- but not histamine-induced secretion in anesthetized dogs. These results suggest that the initial transient inhibition after vagotomy is caused by a specific reduction in the response of gastric mucosa to gastrin. This reduction cannot however be explained in terms of the exclusion of vagal tone which has been established 10 maintain mucosal responsibility to gastrin (14). The following results herein argue against this explanation: 1) tetrapeptide-induced secretion in anesthetized dogs was slightly inhibited only with high doses of atropine, 2) the inhibitory effect of vagotomy on tetrapeptide-induced secretion was transient and soon recovered. In this respect, it is interesting to note that isoproterenol has been reported to inhibit pentapeptide-induced secretion in anesthetized dogs (15), but, on the contrary, enhances histamine-induced secretion (16). Therefore, the most plausible explanation is that transient pre- 
dominance of sympathetic tone is responsible for the initial inhibition of tetrapeptideand morphine-induced secretion. On the other hand, morphine-induced secretion was still depressed even when almost complete recovery from vagotomy occurred in tetrapeptide-induced secretion. The incomplete recovery of morphine-induced secretion is considered 10 be due to decreased gastrin release following vagotomy. The vagal control of gastrin release is well established $(3,17)$. However, central vagal activation does not appear to be the sole mechanism of gastrin release by morphine, because gastric secretion was evident even after vagotomy. Thus it is concluded that not only central but also peripheral cholinergic stimulation of endogenous gastrin release is responsible for the secretory enhancement by morphine.

Histamine-induced secretion in anesthetized and unanesthetized dogs was hardly affected by a dose of atropine, hexamethonium and secretin which inhibits morphineinduced gastric secretion. Such being the case, morphine-induced secretion cannot be attributed to histanine levels in the blood.

Acknowledgements: The author extends his gratitude 10 Dr. S. Kumada, Vice Director of Fujisawa Research Laboratories for helpful discussions and suggestions and to Mr. K. Shimomura for technical assistance.

\section{REFERENCES}

1) Riegel, F.: Z. kin. Med. 40, 347 (1900)

2) Smirnov, A.I. And Shiroki., W.F.: Z. ges. exp. Med. 57, 324 (1927)

3) UvNÄs, B.: Gastroenterology 56, 812 (1969)

4) Grechishkiv, L.L.: Farmakol. Toksikol. 31, 450 (1968)

5) Tilompson, W.L. AND Walton, R.P.: J. Pharmacol. exp. Ther, 143, I3! (1964)

6) Yamaguchi, I., Nakahira, Y., Mori, J., HoNda, F., Kumada, S. and Nishizaki, H.: Japan. J. Pharmacol. suppl. 23, 22 (1973)

7) Elwin, C.-E. And UVNÄs, B.: Gastrin, Fdited by Grossman, M.I., p. 69, University of California Press, Los Angeles, ([966)

8) Hirschowitz, B.I. AND SACHS, G.: Gastroenterology 56, 693 (1969)

9) Blair, E.L., Harper, A.A., Lake, H.J. and Reed, J.D.: J. Physiol. 159, 72p (1961)

10) Bennet, A. and Hogbix, B.M.: $J$. Physiol, 198, $91 \mathrm{P}$ (1968)

11) EMAs, S.: Am. J. dig. Dis. 13, 572 (1968)

12) Johansson, I., Lundell, L. and Svfnsson, S.E.: J. Physiol, 217, 723 (1971)

13) Yamaguchi, I., Fuke, H., Tsujtia, M., Honda, F. And Nishizaki, H.: Japan. I. Pharmacol. suppl. 24, 84 (1974)

14) Andersson; S. AND Olbr, L.: Acta. physiol. scand. 60, 51 (1964)

15) Curwain, B.P. And Holton, P.: Br. J. Pharmacol. Chemother. 44, 322p (1972)

16) Curwain, B.P., Endershy, K. and Holtun, P.: Br, J. Pharmacol. Chemother. 41, 384P (1971)

17) Grossman, M.I.: Fedn, Proc. 27, 1312 (1968) 